\title{
In search of the genes of asthma on the island of Tristan da Cunha
}

\author{
NOE ZAMEL MD FRCPC \\ Mount Sinai Hospital, Toronto, Ontario
}

\begin{abstract}
N ZAMEL. In search of the genes of asthma on the island of Tristan da Cunha. Can Respir J 1995;2(1):18-22.

Asthma, like several common diseases such as diabetes and atherosclerosis, occurs in fimilies and thus probably has a complex polygenic basis, in which environmental factors also play a role. In trying to elucidate the genctic mechanism, studies of communities characterized by a high level of interbreeding and a high prevalence of asthma should be helpful. One such community has been described in the medical literature, the island of Tristan da Cunha. The University of Toronto Genetics of Asthma Project decided to study this community. It sent a team to the island to construct a geneology, obtain a history of respiratory and allergy symptoms by questionnaire, perform allergy skin testing and methocholine challenge, and obtain blood for white cell genetic studies. The initial results of this study are presented here, together with a historical perspective on the people of Tristan da Cunha.
\end{abstract}

Key Words: Asthma, Genetic mechamisms. Tristan da Cunha

\section{À la recherche des gènes de l'asthme sur l'île de Tristan da Cunha}

RÉSUMÉ : L'asthme, comme plusieurs affections courantes telles que le diabète et l'athérosclérose, affecte certaines familles. Cette pathologie a donc probablement une base polygénique complexe à laquelle s'ajoutent des facteurs environnementaux. Afin d'élucider les mécanismes génétiques, des études de communautés caractérisées par un niveau élevé de croisement consanguin et une forte prévalence d'asthme devraient s'avérer utiles. Une communauté de ce type, I'île de Tristan da Cunha, a été décrite dans la littérature médicale. Les responsables du Genetics of Asthma Project de la University of Toronto ont décidé d'envoyer une équipe sur cette île pour y établir la généalogie des habitants, obtenir par questionnaire l'histoire des symptomes respiratoires et des symptômes d'allergie, pratiquer des tests de provocation à la méthacholine et des tests cutanés d'allergie, et obtenir des échantillons sanguins pour l'étude génétique des leucocytes. Les premiers résultats de cette étude sont présentés et sont accompagnés d'une perspective historique sur la population de Tristan da Cunha.

\begin{abstract}
A STHMA WAS FIRST NOTED ON THE ISLAND OF TRISTAN DA Cunha by a missionary, KM Barrow, who in 1910 described the death from asthma of a 12-year-old girl and iold of other nonfatal cases of asthma. In 1923, a visiting ship's physician, F Wild, found asthma to be the most common disease on the island: another ship's physician, EJS Wooley, diagnosed asthma in 97 islanders. of which 27 cases were severe. The Norwegian scientilfe expedition of 1937-38
\end{abstract}

claimed to have convincing evidence that three of the original 15 ancestors suffered from asthma.

As a result of the volcanic cruption in 1961, the entire population of Tristan da Cunha was evacuated to England where they remained for almost two years. During that time they were subjected to 66 studies sponsored by the Tristan dit Cunha Working Party of the Medical Research Council. Virtually every aspect of their health. anthropology, sociol-

Presented at the 63rd Annual Meeting of the Royd College of Physicians and Surgeons of Canada, Septemher 17. 1994

Correspondence and reprints: Dr Noe Zamel, Mount Sinai Hospital. 600 University Avenue, Room 656. Toronto, Ontario M5G IX5.

Telephonc (+t6) 586-4473, Fax (4l6) 586-8558, e-mail noe@ir),org 
ogy, psychology, dietary hatbits and even their peculiar English dialect were investigated. Asthmil prevalence was one of the studies conducted by Citron and Pepys (1). who found that about half of the islanders gave a history of asthma, with wheezing heard in $29 \%$ of the adults and $12 \%$ of the children. Mantle and Pepys (2), in a subsequent study done on the island 10 years after the islanders returned, found that $32 \%$ of the islanders demonstrated objective evidence of asthma over the 16-month study period.

Some years ago the University of Toronto Genetics of Asthma Project group decided to study the community of Tristan da Cunha. The initial contitet was made on February 24, 1992 but it was not until March 17. 1993 that the Island Council approved the study. Before deseribing how the project was done. it is filting to review briefly the island's geography, history and pertinent events related to the study.

\section{THE PAST AND THE PRESENT}

Tristan da Cunhat is an island situated in the South Atlantic Ocean roughly half way between Cape Town and Buenos Aires. It is roughly circular and covers an area of $98 \mathrm{~km}^{2}$, rising stceply from the sea to the $2060 \mathrm{~m}$ peak that reveals the caldera of the original volcano. The island emerged from the mid-Allantic ridge, which extends northwards to St Helena, the Ascension Islands and the Azores. All the islanders live in a small conmunity on a narrow plateau at the foot of the mountain, which they simply call the Settlement. The official name is Edinburgh, so called after the visit of HRH Prince Alfred, the first Duke of Edinburgh, in 1867. The inhabited area is barely $8 \mathrm{~km}^{2}$. It is British territory, and like Ascension Island further north, is a dependency of St Helena.

\section{THE PEOPLE OF TRISTAN DA CUNHA}

The island's people stem from settlers who originated from Scotland, England, Ireland, Holland, Italy, the United States, South Africa and St Helenil. Although first sighted by the Portuguese explorer Tristaio dia Cunha in 1506, Tristan's first settlers did not arrive until 1810 . In that year Jonathan Lambert of Salem, Massachusetts arrived with three companions and shortly thereafter declared himself Emperor of Tristan da Cunha. His reign, however, wals short-lived because there was only one survivor, Thomas Currie. remaining of this group when the British arrived in 1810 .

The first people to settle and raise families were three soldiers who stayed on the island when the British garrison was withdrawn in 1817 . The best known of these men was a Scot, Willian Glass, who is regarded as the founder of the present Tristitn community. He married a woman from Cape Town and they had 16 children. Between 1817 and 1825 four ships were wrecked in Tristan waters and members of their crews stayed for varying periods of time. More permanent settlers came in 1821 and 1826- two Englishmen, Cottor and Swain

An inportant landmark in the history of the people of Tristan occurred in 1827 when al party of 10 people emigrated from St Helena to Tristan - live wonnen, one of them with

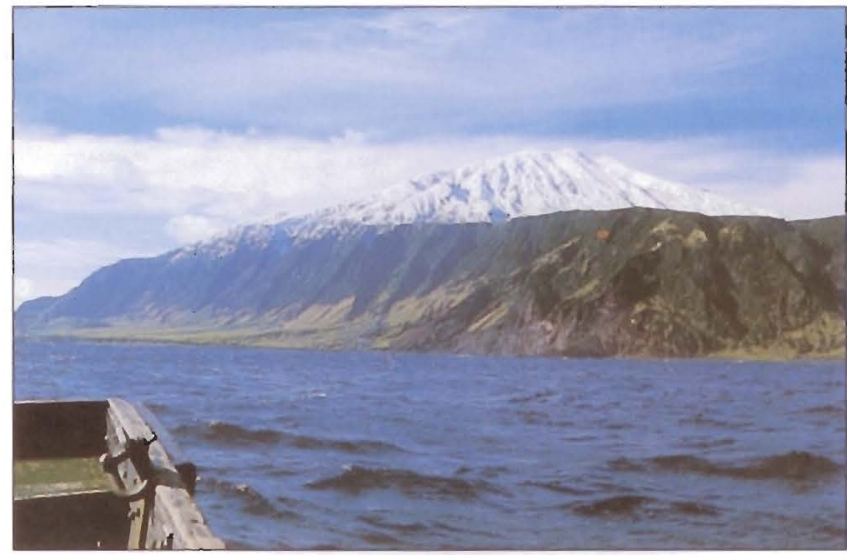

General view of the island. At the extreme left is the narrow plateau at the foot of the mountain where the settl'me'nt and the poutu patches we levated

four children, and a single man. The population was suddenly increased 1024 people - seven men, six women and 11 children. Five of the islanders married women from St Helena. Apparently three of these women from St Helenil (two sisters, one of whom had a daughter) introduced asthma to the island. Ten years later, another shipwreck occurred and three of the survivors, Green from Holland, Miller from Denmark, and Daley from the United States, decided to settle and marry into island families. Peter Green became the leader of the community on the death of William Glass. The next important event was yet another shipwreck in 1892, which resulted in two Italians, Lavarello and Repetto, settling on Tristan. After 1892 many people came and went but in 1908 a new population of settlers appeared when three Irish women, who had married Tristanians in Cape Town, returned with their families to settle on the island. Since then the only new surname to appear on the island is Patterson. in Englishman who married a Tristanian woman. They returned with two daughters to settle on the island in 1986.

\section{MAJOR EVENTS}

The island was relatively prosperous between 1816 and 1885, with frequent visits by whalers and several shipwrecks. During these years there were 17 ships wrecked in Tristan waters. Ships bound for India and the Far East called in for fresh produce and water, which were usually bartered for flour, sugar. teat, tobaceo and clothing. Education for the young was a constant problem - only two missionaries (teachers) arrived and spent at fow years on the island during this period.

The first of three major events that conditioned life on Tristan happened in 1885. At this time the population was 107. In seeking to barter with a passing ship, an island boat with il crew of 15 men was lost; they included 12 married and three single men. The disaster left only four elderly married couples; the rest were women and children on the island. By 1890 some 34 of them had migrated to South Africa. The inevitable question arose - could a community of 64 people survive on the island? This dilemma haunted the islanders 


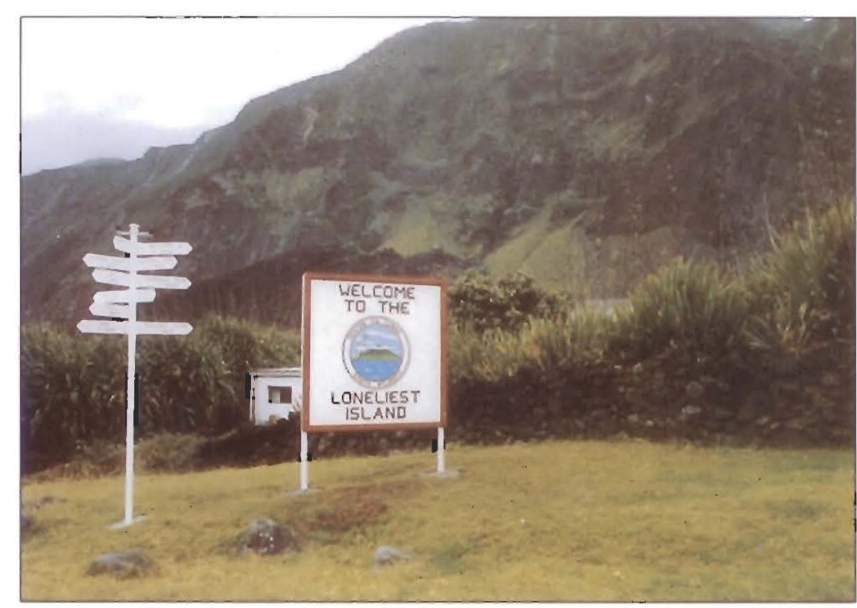

Welcome sign wo the "Leneliest lstand"

and the British government for the next 15 years. It came to a head in 1904. A proposal was made to transfer the whole population to Cape Colony, provided that all the islanders agreed. Of the remaining 16 familics. seven voted in favour of relocating and 10 voted in fievour of remaining, so the offer was withdrawn.

The second event occurred during World War II. A naval station was established in 1942 and the renewed interest in the island resulted in a fishing survey expedition to study the feasibility of establishing a fishing and canning industry. It reccived a favourable report and by 1949 a canning factory hal been built - it has since been the main source of income for the islanders. The men engage in fishing for crayfish or rock lobster while the women and older men clean and pack the cillch at the factory. There are two fishing trawlers owned by the factory, which bring regular supplies from Cape Town. Other parts of the nival station became a hospital and a school. With all these developments the British government appointed an administrator in 1950 with overall authority over the island. Doctors, tcachers, agricultural and development officers are appointed regularly and sent from England to the is Land. However, local politics are the responsibility of the Island Council, which is clected by the islanders along with the Hcild of the Council, the Headman, for a term of three years.

The third event wals at more shattering experience for the islanders. During August 1961 pieces of rock broke from the mountainside behind the Settlement and earth tremors developed. By Octoher a wide fissure had opened near the base of the mountain just to the east of the cottages; the heat and the smell emerging threatened volcanic activity. Everyone was evacuated first to the local fields to the west. known as the Potato Patches, and then to Nightingale Island $40 \mathrm{~km}$ away. From there they sailed for Cape Town. As they passed Tristan, they could see the smoke, cinders and lava gushing from the now active volcano developing at the side of the mountain. The factory on the beach was completely engulfed, but only one cottage was destroyed. From Cape Town the islanders were evacuated to England where they were accommodated near Southampton. After one year in England most of the islanders voted to return to Tristan after it had been inspected and reported to be safe. A new factory and harbour were built, and since then the fishing industry has prospered. Though deeply upsetting, the evacuation led to some benefits for the islanders. The forced stay in England introduced them to a different life style. Their homes were renovated, and many of the formerly thatched roofs were replaced with corrugated sheeting; running water was provided, as was electricity with the completion of the factory.

\section{A TOUR OF THE ISLAND}

The mountain towers above the harbour, and the grayblack, cindery mass of the volcano with its ridge of solidified lava lies to the east of the Settlement. Four kilometres to the west are the Potato Patches, where each of the 90 families cultivates the annual supply of potatoes. Scattered about the Settlement and the lower hillsides are sheep and cattle - each family is allowed to stock only nine sheep and two cows, duc to the limited grazing land.

The school, built in 1975, is staffed by the islanders and provides the children's education up to the age of 15 years. A museum and craft shop displays a history of the islanders and has woolen goods and handicraft work on sale. Nearby is the post office with a valuable assortment of stamps and first day covers: this provides another source of income for the island. The factory, just above the harbour. gives employment to many of the islanders. The products are packed and frozen for shipment to Cape Town and ultimately the markets of France. the United States and Japan.

The administration building houses the administrator's office, the treasury, the police station and a video library. It contains the council chamber - every three years a council of eight islanders is elected to advise the administrator on the making of by-laws and other matters.

Further up the same road is the hospital. It was built in 1972 and is called the Camogli Hospital - Camogli is the seaside village near Genoa in Italy from which the two shipwrecked Italians originated. There is a resident doctor, two nurses and occasional visits from a dentist and an optician.

There are two churches - St Mary the Virgin, which serves the largest group, the Anglicans, and the tiny church of St Joseph's serving the small Roman Catholic community. St Mary's is proud to have received the lirst church organ from Queen Mary, wife of George V; its second and third organ were given by Queen Elizabeth II.

The village hall, which was opened by Prince Philip in 1957. is the social centre for dinces and games; a separate part forms the village pub. An interesting construction behind the hall is the gong, a gas cylinder with the bottom removed. The gong is sounded to announce special events to the islanders such as a fishing day or the distribution of mail.

The commercial and industrial area is centred on and around the site of the former naval station. A supermarket provides a wide selection of frozen, canned and sometimes fresh foodstuffs as well as other items such as clothing. cosmetics, cigarettes, alcohol and soft drinks. The government deparments, agriculture, public works department and 
vehicle yard are close by. The nearby radio station maintain. a regular telecommunications service with the outside world via Cape Town. Radio Tristan broadcasts four days a week and transmits the BBC World Service news. The administrator lives at the Residency where the Union Jack is hoisted each day. Close by are four government bungalows available to visiting officials.

Due to the dangers of swimming in the harbour and surrounding waters, a swimming pool was built near the village hall in 1986. Next door is Jane's Cafe - open for light refreshments each weekday evening. In the fields just below the school are three squared off cemeteries, a testament to the history of the island.

Most cottages have a vegetable patch and can grow cabbage, lettuce, pumpkin, tomatoes and root crops. Families keep their own hens so they are self-sufficient in eggs. Wool from the sheep is knitted into socks, sweaters and other articles. Many of the older women still card and spin their own wool, and some of the older men make model sailboats.

The islanders rarely leave the island. Some travel for further education or work for a period abroad but the majority stay on the island. Presently the emigration from Tristan is virtually nil.

\section{LANGUAGE}

The English dialect spoken on Tristan da Cunha is unique. Their grammar and use of tenses are confusing to other English speakers. "Where you all was?" is their equivalent of "Where were you all?". They have a tendency to add a strong $\mathrm{h}$ in front of words starting with vowels. For instance they pronounce "Albert" as "Halbert". "Asthma" is pronounced "hashmere". The "islanders" are "highlanders". "Cough" is "tissick", "dogs" are "dongs" and "donkeys" are "dornkeys". "Surf" is "sarf", "Herbert" is "Harbert" and "learning" is "larning". Also, there are some Dutch influences, so that "fardi" means "godfather", and "kappie" is a little girl's bonnet. The most striking Dutch influence is the use of the torossive pronoun: "this is mine, that's you'n, those are they'sn".

\section{COMMUNICATIONS}

The main external link with the island is Cape Town in South Africa. The crayfish company is based there and its fishing vessels call on Tristan about six times a year - they have accommodations for a few passengers, but some space is always kept in reserve for urgent medical cases from Tristan. The RMS St Helena is the only regular passenger ship - it calls at the island on route from England to Cape Town just once a year. The occasional cargo or naval ship will call, but these are infrequent and depend upon special cargoes.

\section{CLIMATE AND NATURAL HISTORY}

The climate is temperate and oceanic with rapid weather changes, a wide temperature range of $4^{\circ} \mathrm{C}$ to $24^{\circ} \mathrm{C}$ and frequent rain averaging $165 \mathrm{~cm}$ at year. The peak of the island, the original volcanic conc, is often covered with snow, but the settlement plateau is frec of liost and snow.
The seas around the island are teeming with fish ranging from the common five fingers and crayfish to mackerel, snoek and steambras. A number of birds and mammals are fully protected, including the Tristan thrush, island cock, the wandering albatross, and various species of seals and the southern right whale. In different parts of the island various kinds of penguins have established rookeries. Seals abound in the seas and can be seen lounging on the rocks. On the upper slopes of the island yellow-nosed albatross nest in large numbers.

There are spectacular views from the top of the first crest of hills - a plateau some $600 \mathrm{~m}$ high where sheep graze on the rich vegetation. It can be reached after a stiff hill climb of about one hour; climbing from there to the peak of the island takes another few hours. Due to the changeable weather conditions all such climbs must have an islander as a guide.

\section{THE STUDY}

Our objectives were to construct a genealogy, obtain il history of respiratory and allergy symptoms by questionnaire, perform allergy skin testing and methacholine challenge and obtain blood for white cell genetic studies. Before our arrival, the medical officer on the island, Dr Peter R Sandell, obtained a detailed respiratory symptom questionnaire and conducted allergen skin prick tests to 15 common allergens on virtually all islanders older than five years of age. The total population of the island in October 1993 was 301; data were obtained from 282 subjects.

The members of the University of Toronto Genetics of Asthma Project who went to the island were me and Mrs Patricia A McClean, research associate of the Trihospital Pulmonary Function Laboratories of the University of Toronto. We carried with us equipment to perform methacholine challenges by the Cockcroft method, using a computerized bronchial challenge system. We also took with us all the materials required for blood sampling and storage.

We left Toronto on September 20, 1993, arriving in Cape Town on September 22. We departed for Tristan da Cunha on September 23 aboard the SA Agulhas, a South African oceanographic research vessel $100 \mathrm{~m}$ long, with a crew of 42 . The trip typically takes one week between Cape Town and Tristan da Cunha. This part of the South Atlantic Ocean is called the Roaring Forties due to the strong winds and very rough seas. The ship rolled 20 degrees for most of the journey and on the fourth day we experienced a roll of 45 degrees. One person who was on the deck was propelled towards al low railing, unable to stand on the sloping deck. If he had not fallen flat on his back he surely would have been swept overboard. At that time cabins were flooded, furniture was damaged and it was amazing that no one was injured. The captain later said, "We like to make each voyage memorable!".

In the early morning of September 29 we awokic to the spectacular sight of a mountain rising out of the ocean. The disembarkation from the SA Agulhas was accomplished by hoisting the passengers in a crate down to a small motor boal tossing in the waves below. Tristan's shallow harbour cannot 
accommodate large vessels. Once we arrived and thankfully kissed the land, we were welcomed by the smiling islanders and a big sign saying, "Welcome to the Loneliest Island in the World". This is definitely not an exaggerated claim. We and the other passengers who came to work on the island for a period of about one month, before the SA Agulhas was scheduled to return, were lodged in three guest houses. Each guest house was equipped with three bedrooms, a common room, washroom and kitchen. We were provided with a crate of island potatoes, a daily supply of fresh (still warm) milk and one small space heater to huddle around while the wind howled ceaselessly outside. From then on it was work for 10 hours a day, six days a week, doing methacholine or bronchodilator challenges using two sets of equipment. The coopcration and the level of enthusiasm of the islanders was overwhelming.

The SA Agulhas was scheduled to pick us up from Tristan dat Cunha to return to Cape Town on October 22. In order to minimize the transportation time for the blood, which had to be kept at $4^{\circ} \mathrm{C}$ and could he reliably stored for no more than 12 days, we sampled all the subjects on one day (October 20 ). The following day we transpoted all the blood samples to at refrigerator on the SA Agulhas using the ship's helicopter because of rough sea conditions. That evening we hosted a large celebration that was attended by virtually the entire community. We danced at the Prince Philip Hall until 3 AM the next day (October 22) when we left Tristan da Cunhal.

There are many stories to tell of the time we spent on the island, all of them are extremely pleasant, apart from one painful experience I had with a kidney stone that started moving on the day of the blood collection. Thanks to strong pain killers I was able to sample blood of 90 subjects $(40 \mathrm{~mL}$ from aich person) while Pat McClean and Peter Sandell managed similar quotas. We arrived in Cape Town on October 28 and finally in Toronto on October 30. By November 2, all the DNA was successfully extracted such that not one sample was lost.

Genealogy: We now have virtually complete data describing the family trees, including all the islanders and extending to the very first settlers on the island, starting with William Glass. The level of inbreeding is so high that all the islanders are cousins and on average two siblings are cousins according 1050 different pathways.
Incidence of asthma: When wo combined the results of the elinical questionnaire information with the methacholine or bronchodilator challenge results we found that 56 subjects $(21 \%)$ had strong evidence of asthma, 96 subjects $(35 \%)$ had partial or questionable evidence of asthma, and 120 subjects (44\%) had no evidence of asthma. The latter group, however, includes a considerable number of young subjects who may develop asthma in the future.

Incidence of atopy: Skin testing showed that neitrly hatl of the subjects had positive skin challenges, expecially to house dust mites. Interestingly. a considerable number of the atopic individuals (approximately 40\%) were semsitive to cat fur extract. However, all the cats were killed about 20 ycars ago because of toxoplasmosis, and ever since there have been no cats on the island. Some of the subjects sensitive to calt have never encountered a cat in their lives.

Genetic studies: All the blood samples were rapidly processed and the leukocyte DNA successfully extracted. Radioactive DNA probes having molecular sequences that map individual genes were sequenced with electrophoretic separation followed by autoradiography; presently the chromosomes of all subjects have been mapped and linkage analysis is underway. DNA markers representing different sites along the 23 chromosome pairs are examined for segregation of the markers among all subjects. The statistical analysis. referred to as linkage analysis, identifies any marker that cosegregates with the asthma phenotype (defined as airway hyperresponsiveness to methacholine associated with a clinical history of asthma). Because the chromosomal position of each marker is known, demonstration of cosegregation of a given marker with the asthma phenotype allows identification of the chromosomal position of a potential asthma susceptibility gene.

We hope that this unique study will have been worthwhile. and the gene(s) of asthma will be isolated.

\section{REFERENCES}

1. Citron KM, Pepys J. An investigation of asthma among the Tristan da Cunha islanders. Br J Dis Chest 1964:58:1 I9-23.

2. Mantle J, Pepys J. Asthma amongst Tristan da Cunha is Landers. Clin Allergy 1974;4:161-70.

3. Cockeroft D, Killian D, Mellon A, Hargreave F. Bronchìl reactivity to inhaled histamine: a method and clinical survey. Clin Allergy 1977;7:235-43 


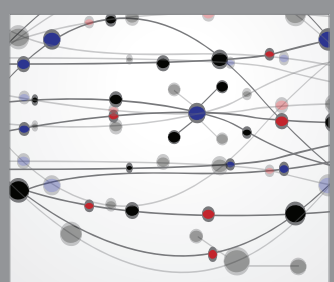

The Scientific World Journal
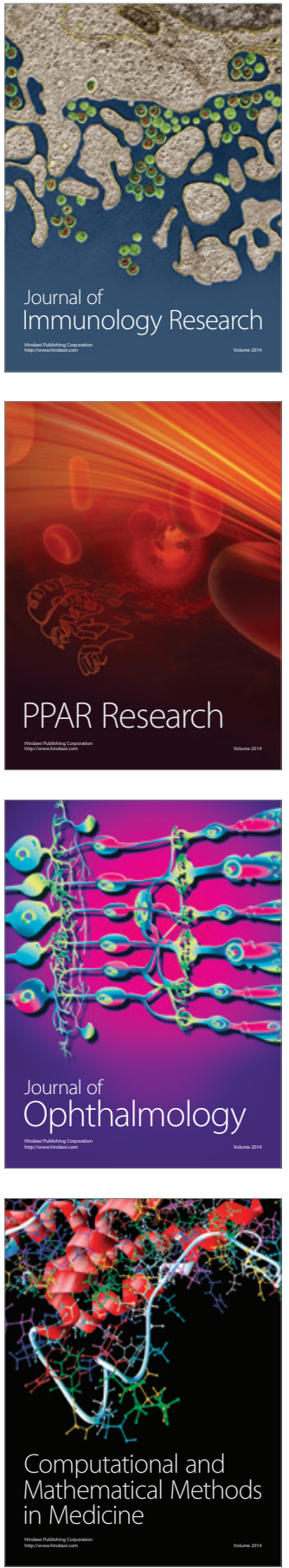

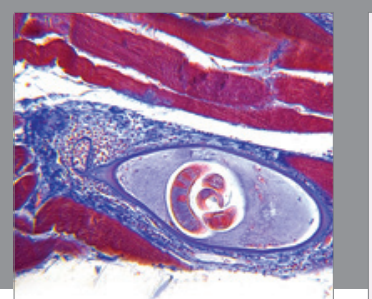

Gastroenterology Research and Practice

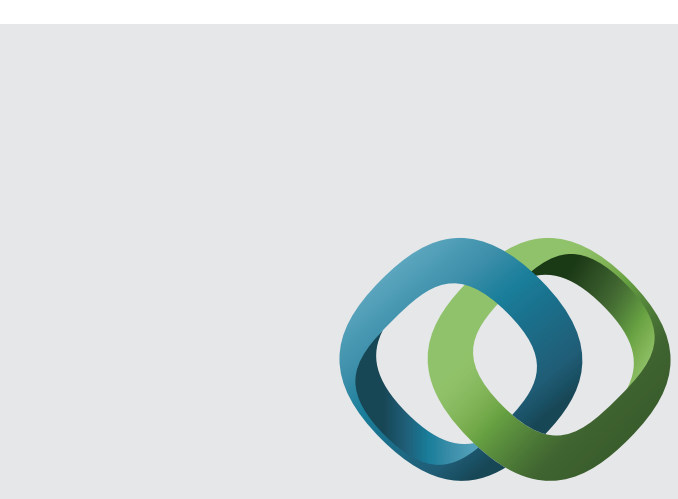

\section{Hindawi}

Submit your manuscripts at

http://www.hindawi.com
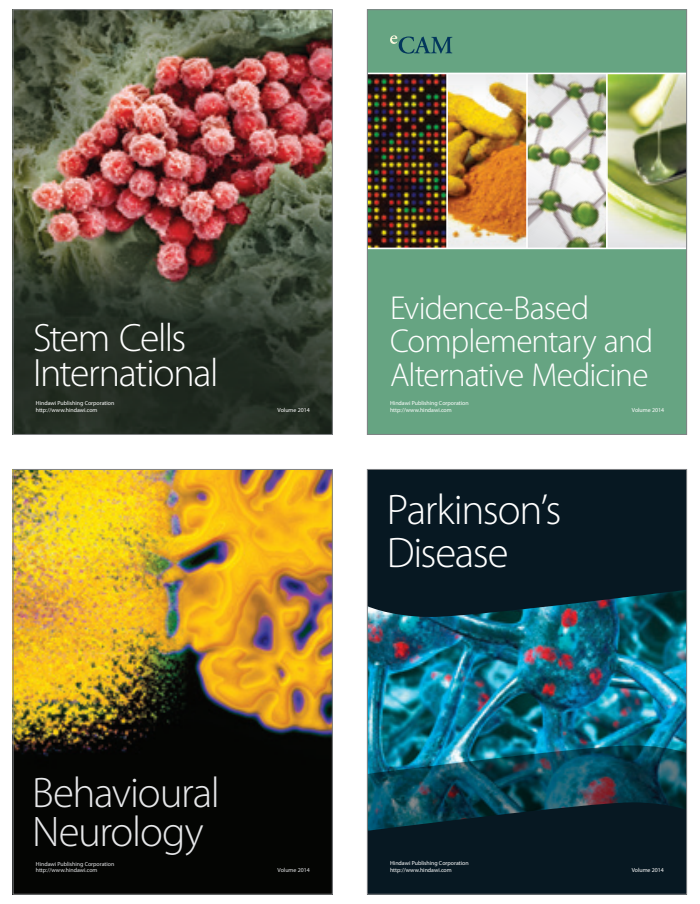
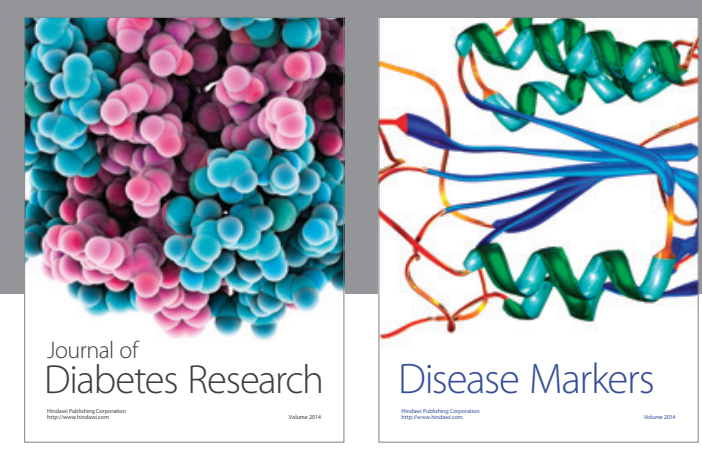

Disease Markers
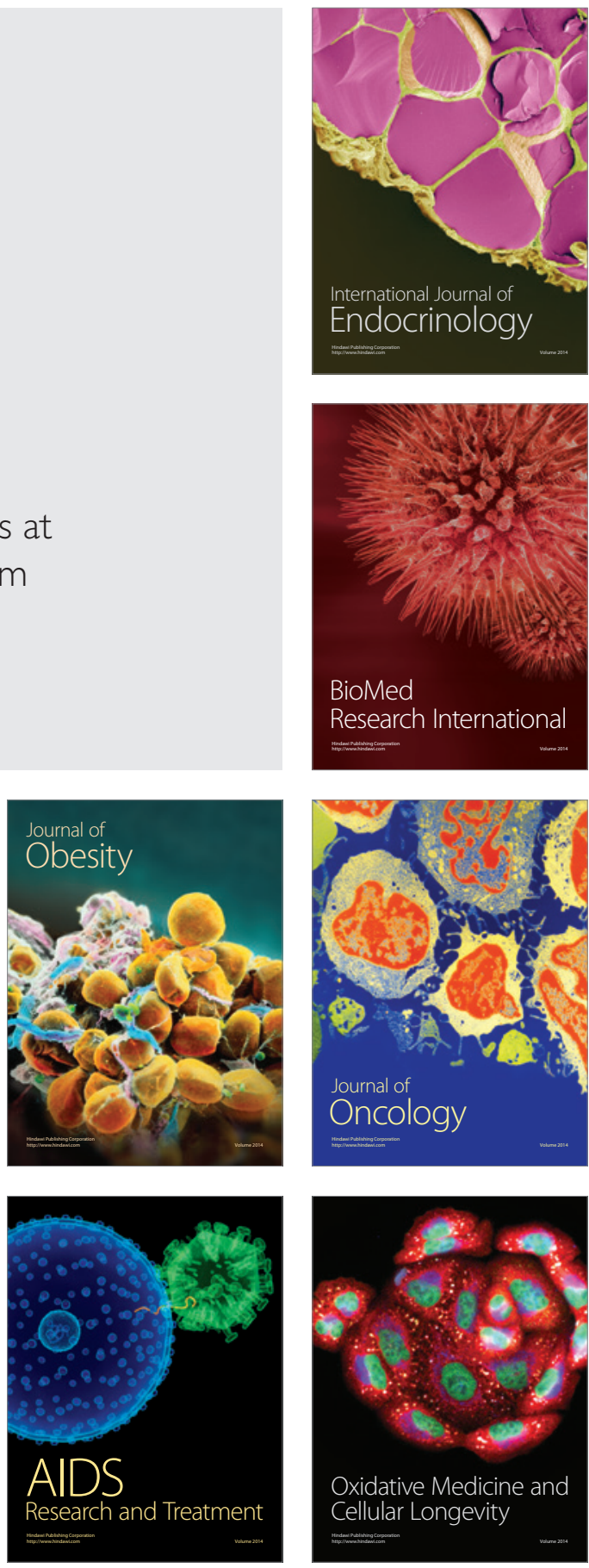